\title{
Rapid change of strategy is necessary for development of dromedary camel pastoralism in the Cholistan desert of Pakistan
}

\author{
Abdul Raziq Kakar ${ }^{1 *}$, Kerstin de Verdier ${ }^{2}$ and Muhammad Younas ${ }^{3}$
}

\author{
* Correspondence: \\ raziq2007@gmail.com \\ ${ }^{1}$ Society of Animal, Veterinary and \\ Environmental Scientists (SAVES) \\ and Department of Livestock \\ Management, Faculty of Animal \\ Husbandry, University of \\ Agriculture, Faisalabad, Pakistan \\ Full list of author information is \\ available at the end of the article
}

\begin{abstract}
The Cholistan desert is part of the ancient Hakra River civilization, one of the oldest of the Aryan settlers in the Indian subcontinent. It is one of the largest deserts in Pakistan, inhabited by around 1.2 million Rohi pastoral people practicing mobile livestock husbandry. This production system is extremely important for food security and conservation of livestock and landscape. The camel is one of the important animal genetic resources and about 80,000 are found in the desert. The main tribe with camel herds is Marrecha. The desert pastoralists also raise goats, sheep and cattle breeds. The major camel breed is Marrecha following by Brela. The precious camel genetic resources are under threat due to commercial agricultural practices, land grabbing and faulty development projects. The policies come from the top and pastoral peoples do not participate in formulating strategies for development. Hence the projects are not supported by local livestock keepers and always result in failure. There is an urgent need to save this pastoral livestock system, especially the camel breeds. It is suggested that niche marketing, value addition, ecotourism and participation of pastoral people in development policies may help achieve this goal. Organization of the livestock keepers in the region can be an efficient tool to halt land grabbing
\end{abstract}

Keywords: Pakistan camel, pastoralists, land grabbing, biodiversity, value addition

\section{Background}

The pastoral people of the Cholistan desert move with their livestock year-round. They travel in search of forage and water, stay some time and then move on. Generally they use camels, donkeys and horses for moving. In the desert ecosystems, the pastoral people prefer camels. which not only provides draft power for transporting goods but also provides food in the form of milk when other livestock species cease milk production in the dry and harsh seasons.

The pastoral livestock species are well adapted to the local ecology and produce under very low input conditions. Pastoral livestock breeds are embodied with the indigenous knowledge, aesthetic sense and cultural values of their keepers. The pastoral people have been using their indigenous knowledge for breeding, feeding and health care in harmony with the environment. In scenarios of climate change and global warming, the welladapted livestock species of the pastoral people assure food security (Raziq 2009b).

This system of livestock keeping is under threat due to many unfortunate circumstances. Though comprising an important part of the local society, the pastoralists are

\section{SpringerOpen ${ }^{\circ}$}

(c) 2011 Kakar et al; licensee Springer. This is an Open Access article distributed under the terms of the Creative Commons Attribution License (http://creativecommons.org/licenses/by/2.0) , which permits unrestricted use, distribution, and reproduction in any medium, provided the original work is properly cited. 
still neglected when policies are being made for so-called development. It is strongly believed that without the participation of the pastoral/indigenous people, the Millennium Development goals of the United Nations cannot be achieved properly in the regions where pastoral people live (Cordone et al. 2009). They are not properly valued in the UN programmes and other donor agencies which make policies together with national states. The policies affecting pastoral people must be formulated with the participation of these pastoral communities.

\section{Cholistan desert}

Cholistan desert is a part of the ancient Hakra River civilization, one of the oldest civilizations of the Aryan settlers in the Indian subcontinent. Situated in southern Punjab (latitudes $27^{\circ} 42^{\prime}$ to $29^{\circ} 45^{\prime}$ in the north and longitudes $69^{\circ} 52^{\prime}$ to $75^{\circ} 24^{\prime}$ in the east), Cholistan is part of the Great Indian Desert and one of the largest deserts of Pakistan. The total area of Cholistan desert is 10,399 square miles (2,693,328 ha). The temperature varies from $6^{\circ} \mathrm{C}$ to $50^{\circ} \mathrm{C}$ in winter and summer respectively. The mean annual rainfall varies from less than $100 \mathrm{~mm}$ in the west and $200 \mathrm{~mm}$ in the east (CDA 2009). Most of the Cholistan is covered with a wide range of nutritious and drought tolerant vegetation species.

The water sources available in the desert are comprised of the toba system and tube wells provided by Cholistan Development Authority. A toba is a pond, where rain water is collected and used by all the inhabitants of the desert (Figure 1).

\section{Pastoralists in Cholistan}

Pastoralists provide services which are economically important to the country. They have developed and preserved unique breeds of livestock and traditional knowledge

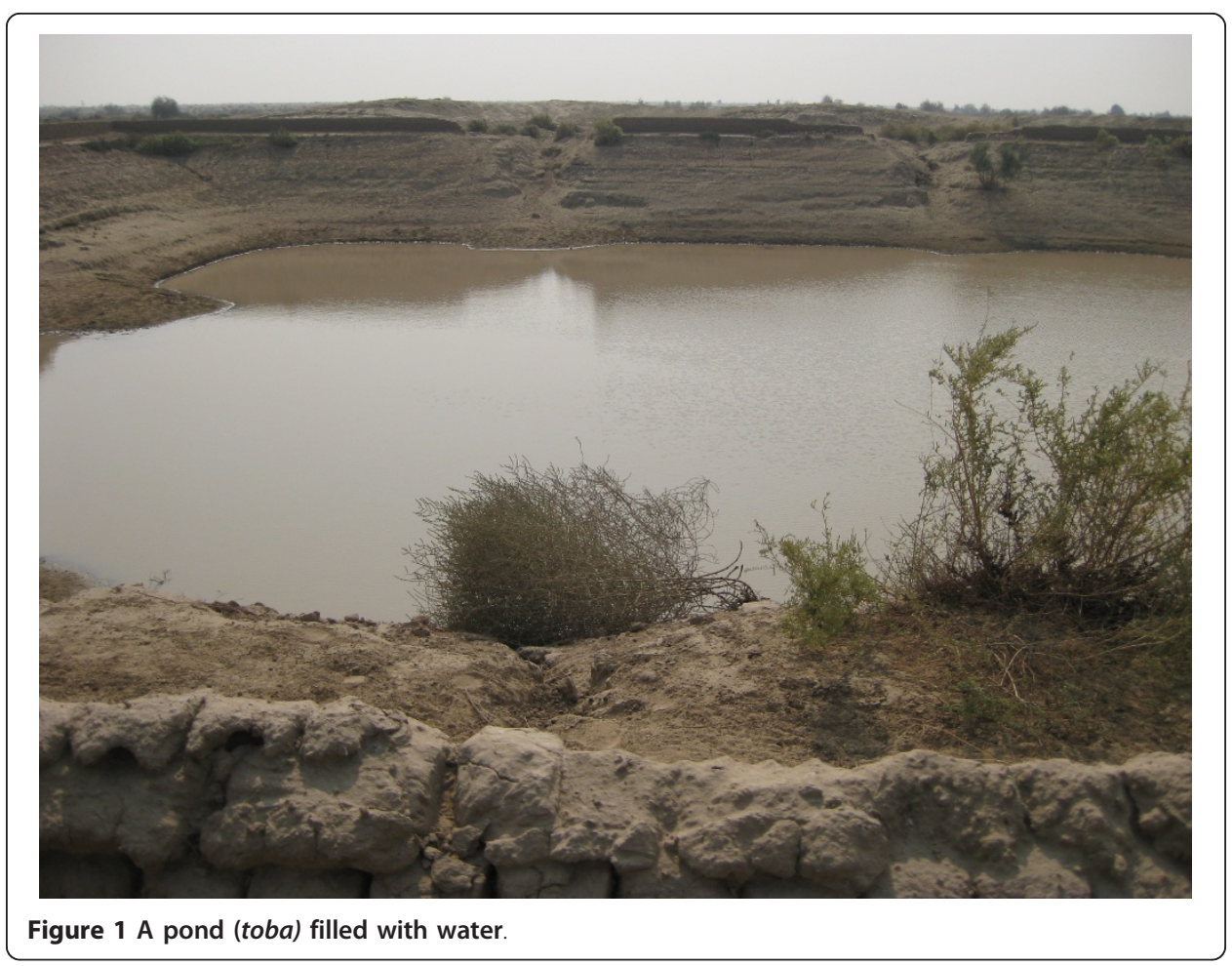


associated with them, and their lifestyle has developed the co-evolved ecosystem which they have traditionally conserved and sustainably used.

The pastoral people have adopted a very good strategy to keep the livestock production system viable. In the time of scarcity, they move along the roads and railway tracks towards the adjoining irrigated areas and rely on the vegetation available along the water courses and road sides. Whenever they stop for temporary work as labourers in the fields, their livestock browse the aftermath of the crops. Some pastoral herds migrate from the Thal desert (in central Punjab of Pakistan) to Cholistan in August and stay there for 5 months and then go back to Thal and the nearby irrigated areas.

The pastoralists know the cultural events along their migratory routes and hence they participate in the fairs (melas) to sell their male animals and milk. They also stay near the peripheries of the cities to sell camel milk, which is usually mixed with buffalo milk by middlemen. Usually the pastoral women sell the camel milk and the earnings go to them (Figure 2).

Cholistan has important drought resistant livestock species but the camel is the most important. The pastoral people love their camels. The scanty and rough vegetation and the hostile environment can only be utilized by this hardy animal. Except for short wet periods, camels mostly rely on the woody and bushy vegetation (Table 1). The camel has been used in the desert for centuries for food and transportation and also plays a pivotal role in socio-cultural activities. When other livestock are dry, the camel provides milk which is the only nutritious food for the desert inhabitants in the long, dry and hot summer days. The herders milk the camel cows when they need milk and the rest is allowed to be suckled by their calves. The camels are also used for riding to gain accessibility to the different parts of the desert.

When pastoralists need money, they sell camels locally and in regional famous camel fairs, such as Channan Peer fair. The average price is 80,000 PKR (about 1,000 USD) but some animals may attain a price of more than 6,000 USD, depending on their beauty and attractiveness.

\section{Camels in Cholistan}

The Pakistani camel breeds are highly diversified at inter and intra breed basis (Raziq 2009,b). Cholistani pastoralists keep two distinct camel breeds, Marrecha and Brela. The production systems and the characteristics of these breeds differ.

Marrecha herders' top priority is to produce draught camels for transportation of goods and families in the desert. They consider hardiness, intelligence and obedience as important special traits for their camels. As the Marrecha breed is in high demand for its racing ability and beauty, the herders stress its aesthetic traits. Marrecha camels have good milk production ability in the desert ecology, thus herders also select for more milk to sustain human life in the desert.

The coat colours of the Marrecha camel range from blackish brown to light brown, with a fawn majority. The Marrecha camel has unique body features and can be easily differentiated from all the other Pakistani breeds. It has long legs and long slender neck, medium head with protruded nose and small pointed rabbit-like ears, long eye lashes and long hair on the ears and neck (Figure 3).

The male animals are trained for many events and riding in the desert. There is high demand for Marrecha camels by race hobbyists in local markets and the Middle East. 


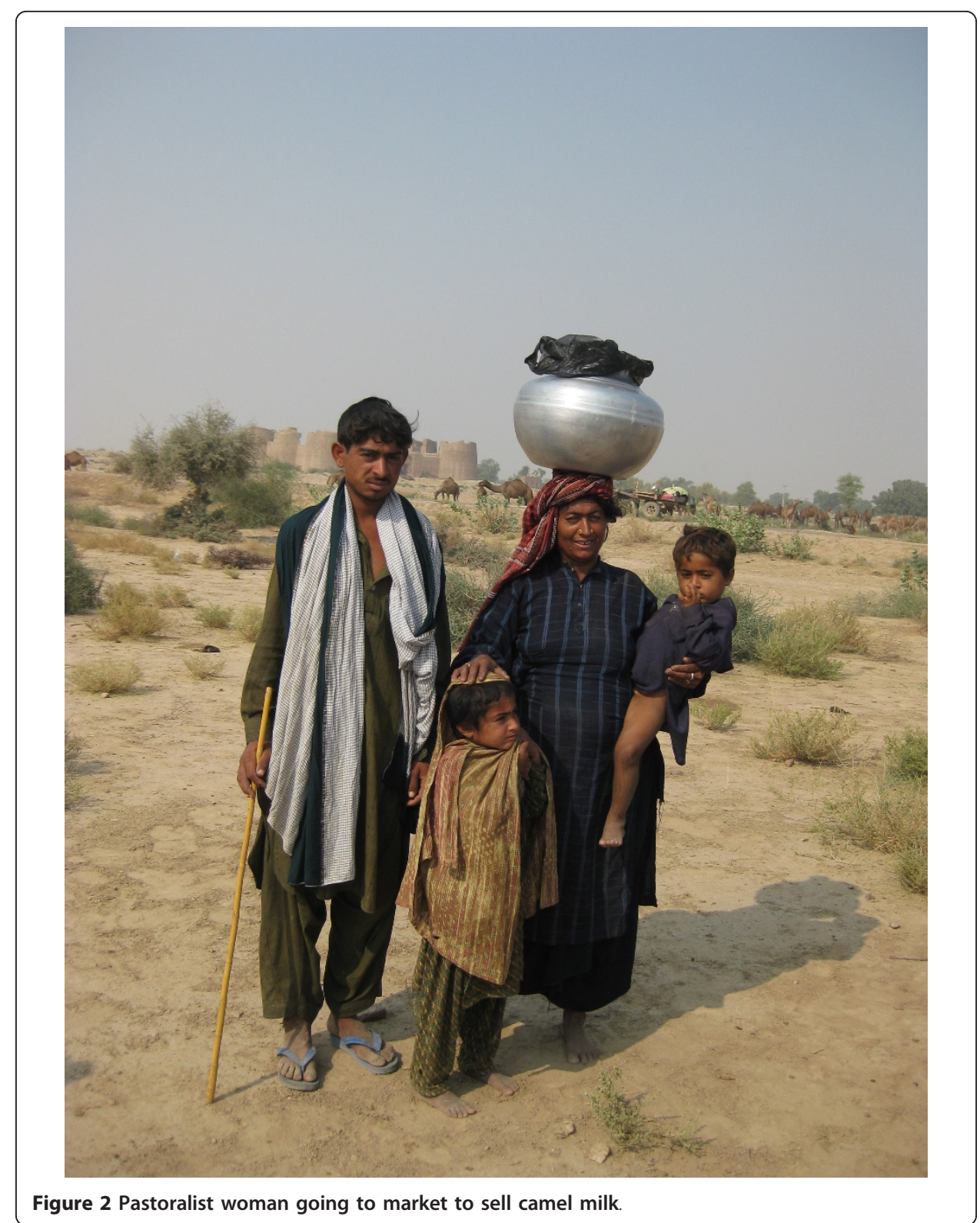

The Marrecha camel is liked by city carters for heavy duty draught power. It produces milk in harsh conditions with high ambient temperatures and scarcity of feed and water. These characteristics of the Marrecha camel enable camel herders to live and stay deep in the desert. The Marrecha pastoralists have an average herd size of 37 camels, majority female (20-25\% lactating cows).

Table 1 Vegetation available for camel in Cholistan desert

\begin{tabular}{llll}
\hline & Trees & & Bushes \\
\hline Local Name & Botanical Name & Local Name & Botanical Name \\
\hline Karir & Capparis aphylla & Khar & Suaeda fruticosa \\
Jand & Prosopis cineraria & Lana & Haloxylon salincornicum \\
Kikar & Acacia nilotica, & Lani & Salsola foetida \\
Mallah & Zizyphus nummularia & Jand & Prosopis cineraria \\
\hline
\end{tabular}

Source: Noor 1989 


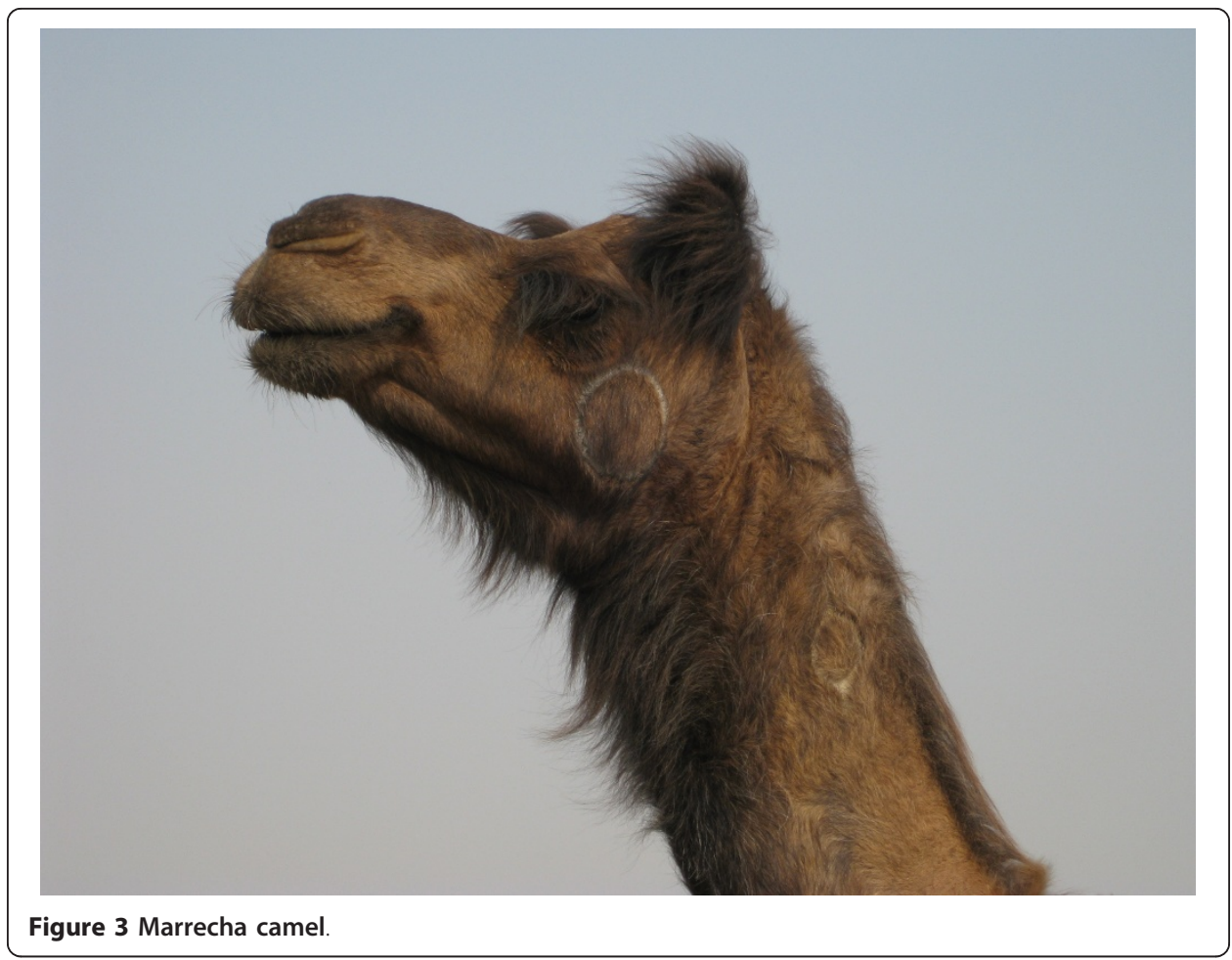

Herds of Brela camels are a bit smaller, with an average of 26 animals. The majority of the camels are female. Lactating females range from $23-27 \%$ of the herd but depend upon the status of the year (dry or wet). The colours range from blackish brown to light brown while the majority is deep brown, and sometimes white specimens are also found. Brela is one of the massive Pakistani camel breeds, with a thick wide neck, wide chest, muscular legs and massive head. The hanging lip is one of the salient features (Figure 4).

The Brela camel is mainly raised for milk and male animals are sold for meat. The Brela is one of the higher milk producing animals, producing up to 22 litres per day with a lactation length of 9 months (Raziq 2009b). Brela camels are milked very regularly twice a day. The docility of the breed is a special trait; a Brela camel would allow a stranger to milk it any time.

\section{Threats to pastoralism in Cholistan}

The situation in the Cholistan desert has become very complex, including pressure on pastoral lands, commercialization of the desert, faulty government policies, marketing issues and poor health cover. Socio-economic and environmental changes make pastoralism tricky throughout the world and Cholistan is one of the worst affected areas. The camel is most vulnerable to the effects of these changes.

A new move in the region to bring more land under cultivation for cotton production is apparently very eye-catching, but there are many side effects of this practice. Land grabbing is one of the important issues, as the grazing lands are decreasing with the intensity of grabbing. The two deserts (Thal and Cholistan) are the homelands of very rich cultures, wide biodiversity of flora and fauna and beautiful landscapes. As FAO (1992) stresses, the in situ conservation of flora and fauna genetic resources is an 


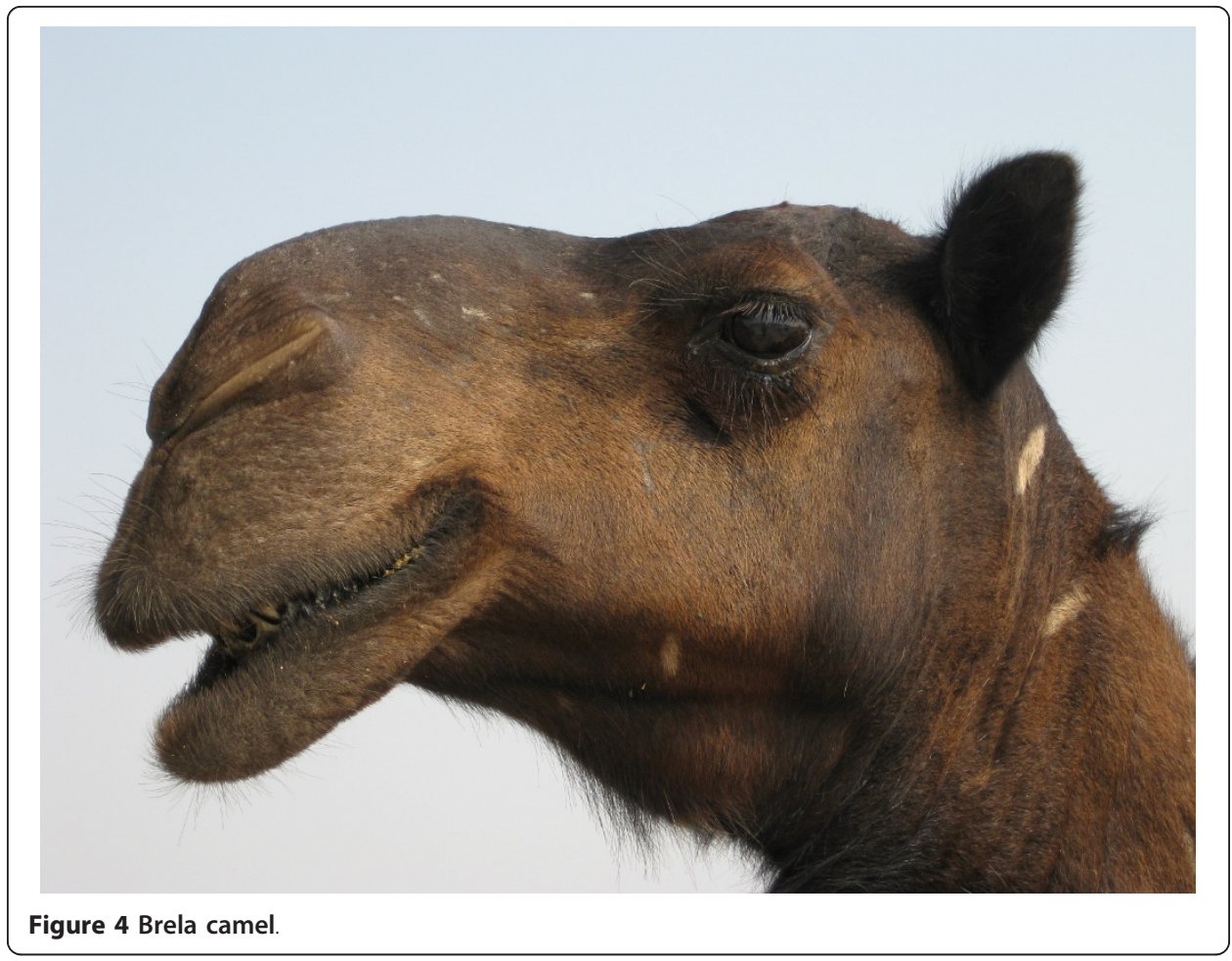

essential tool for food security in the near future. The flora genetic resources can also be used for human and animal health care in the future. The cultivation of land for cotton is a threat to those valuable genetic resources.

Part of the Thal desert has already been brought under cultivation by canal irrigation from the river Indus and the land was allotted in majority of cases to the influential people in the country. The Brela camel herders and other livestock keepers of Thal have been excluded and never compensated for their losses. The small ruminant and cattle breeders have already left the occupation of livestock husbandry but like in other parts of the world, the camel herders adapted a new way by moving long routes with their camels and traveling up to the desert of Cholistan. The land grabbing pushes the livestock deep into the desert; the situation puts more pressure on the desert rangelands of the region.

Increasing the designated area for cereal production and decreasing the area for livestock production is not wise. Cereals need high inputs and irrigation and are therefore unsustainable under desert conditions Cereal production favors the pockets of rich people but does not enhance food security.

Along with the squeezing of grazing lands, together with commercial pressure, water scarcity is a tremendous problem for the pastoral people. During drought periods, the tobas dry up and no water is available. This provokes the Marrecha pastoralists to migrate to irrigated areas, resulting in cultural chaos and conflicts with agricultural farmers.

Camel health is another problem for the pastoralists. Trypanosomosis (surra) and mange are the most common diseases of camels. The veterinary cover provided by the government in the region is quite poor and the drugs available for treatment are very expensive in the nearby markets. The unavailability of veterinary attention and 
medicines increases camel morbidity and mortality. There is also lack of understanding and confidence between veterinarians and local pastoral people. The veterinarians usually are from the urban areas and consider the pastoral people as lower in position. The pastoral people do not trust the veterinarians and think their way of treatment is fake. Therefore the pastoralists mostly rely on indigenous treatments and ethnoveterinary medicine.

When formulating development projects, the government always nullifies the role of the livestock keepers and back short cut methods, such as cereal cultivation, land allocation and crossbreeding the valuable indigenous animal genetic resources with exotic breeds. This strategy is devastating, and is it clearly not possible to reach the Millennium Development goals of the UN in the Cholistan region, if small stockers are deprived of their livestock.

\section{Opportunities for development}

Conservation of the Cholistan ecosystem is important both for the present needs and future challenges.

In Pakistan there is a deficiency of animal origin protein (meat, milk and eggs) in contrast to energy deficiency (cereals) which is found in other parts of the world. Despite many problems, there are also good opportunities for development of livestock production in Cholistan. Indigenous livestock breeds can be used by small holders as a tool against poverty. Camels, as the most important animal of the desert ecosystem, can be a tool to combat the new challenges of drought, environmental changes, global warming and creeping desertification, threats of new disease and competition for feed and water resources. Development of camel milk can be instrumental for the sustainability of camels in the ecology of Cholistan. Many by-products can be made from camel milk and markets can be found for the products. Holding fairs and milk contests can also encourage the camel herders to improve milk production. Value addition is a way to make camel production profitable i.e. making kurth (hard, dry cheese), sorain (sour drink), ice cream, chocolates and other products (Raziq et al. 2010). With the collaboration of World Health Organisation (WHO) or similar agencies, camel milk products can be made available for schools to combat malnutrition on one hand and to support camel herders on the other hand. Hence, camel milk can also be useful for poverty alleviation.

Improving the racing ability of the Marrecha breed is another avenue to make camels more economically sustainable. There is a high demand for racing camels in the rich Gulf countries. This improvement will not only economically benefit the herders but also can be a good source of revenue for the country.

Today, only the herders' surplus camels are slaughtered and interest from Pakistani consumers in camel meat is limited. However, camels have a good potential for meat export to the rich Gulf countries. Camel meat is produced organically and is also free of zoonotic diseases such as mad cow disease, swine flu, avian influenza. Under ordinary grazing conditions, a daily growth rate of $733 \mathrm{~g}$ has been reported (Bissa 1996). In fattening units and feedlots up to $1.5 \mathrm{~kg} /$ day can be obtained with good feeding and supplementation.

Exploitation of niche products (handicrafts from camel wool, skin products etc) is another approach, being used by small livestock keepers for the conservation of breeds 
in many parts of the world (LPP et al. 2010). Eco-tourism (racing, safaris) is one more avenue for fortifying camel production. Camel fairs and safaris are attracting thousands of people from around the world in many countries.

Community development and social mobilization of the pastoral people in the Cholistan desert can bring some economic development, as for example Indigenous Livestock Breeders Association (ILBA) of livestock keepers in Baluchistan which assists in strengthening the community. Social and community enterprises of value addition to camel milk can strengthen the pastoralists on a sustainable basis. Camels yield a reasonable amount of milk in Pakistan (Raziq et al. 2008) and the Brela and Marrecha camel breeds are the best of them. The Marrecha and Brela camels are not officially recognized by the government. Local breeds are often overlooked because science uses different classification criteria than local people. Documentation of the breeds and also support to their use could be enhanced by closer collaboration between government and science with pastoralists.

\section{Conclusion}

The desert ecosystem is suitable for sustainable indigenous livestock production systems, especially based on camels. Pastoralists provide services which have economical and socio-cultural importance to the country.

Indigenous livestock breeds can be used by small holders as a tool against poverty. Closer collaboration between government and science with pastoralists would enhance documentation of the breeds and also support to their use.

Recognition and participation of pastoral livestock keepers are keys to success.

\section{Author details}

${ }^{1}$ Society of Animal, Veterinary and Environmental Scientists (SAVES) and Department of Livestock Management,

Faculty of Animal Husbandry, University of Agriculture, Faisalabad, Pakistan ${ }^{2}$ Dept of Animals Health and Antimicrobial Strategies, National Veterinary Institute (SVA), 75189 Uppsala, Sweden ${ }^{3}$ Department of Livestock Management, Faculty of Animal Husbandry, University of Agriculture, Faisalabad, Pakistan

\section{Authors' contributions}

All authors participated in collecting data. ARK and KdV drafted the manuscript. All authors read and approved the final manuscript.

\section{Authors' information}

Abdul Raziq Kakar (raziq2007@gmail.com) is a researcher and president of the Society of Animal, Veterinary and Environmental Scientists (SAVES). He is engaged on research and development issues of the livestock pastoral people in Pakistan. He completed his PhD on camel and pastoralism from the University of Agriculture, Faisalabad, Pakistan. Kerstin de Verdier (Kerstin.de-verdier@sva.se) is a veterinarian, PhD and researcher at the Swedish National Veterinary Institute, on ruminant and camelid issues.

Muhammad Younas is professor and dean at the Faculty of Animal Husbandry, University of Agriculture, Faisalabad, Pakistan.

\section{Competing interests}

The authors declare that they have no competing interests.

Received: 28 January 2011 Accepted: 9 May 2011 Published: 9 May 2011

\section{References}

Bissa, UJ. 1996. Early growth and its association with certain blood parameters in different breeds of camel. In M.V. Sc. thesis. Volume 12. Department of Animal Breeding and Genetics. College of Veterinary and Animal Science, Rajasthan Agricultural University, Bikaner. Camel Newsletter 21-23.

CDA 2009. Facts sheet about Cholistan. Cholistan Development Authority, CDA Bahawalpur Pakistan.

Cordone, A, A Raziq, I Köhler-Rollefson, and L Pat. 2009. Millennium Development Goals, Indigenous Peoples and IFAD's. http://w3.uniroma1.it/sapienzamillenniumcourse/MDGIFAD2009UNIVERSITY.pdf.

FAO 1992. In situ conservation of livestock and poultry. In Animal Production and Health Paper No. 99, Romeed. Henson EL GOP 2008. Government of Pakistan. Pakistan Census of Livestock 2006. Agricultural Census Organization (ACO), Statistics Division, Lahore. 
LPP, LIFE Network, IUCN-WISP and FAO 2010. Adding value to livestock diversity-Marketing to promote local breeds and improve livelihoods. FAO Animal Production and Health paper. No. 168. Rome.

Noor, , and Mohammad. 1989. Rangeland Management in Pakistan. Published by the International Centre for Integrated Mountain Development (ICIMOD) Kathmandu, Nepal.

Raziq, A, M Younas, and Z Rehman. 2010. Prospects of livestock production in Balochistan. Pakistan Veterinary Journal. 30(3) http://pvj.com.pk/in_press/9109.pdf.

Raziq, A. 2009. Unpublished field observations. Visit to Cholistan desert.

Raziq, A. 2009. Assessing the potential of the indigenous livestock breeds of Balochistan. Drynet: A science and technology expertise. Project study report, funded by the European Union and supported by The Global Mechanism.

Raziq, A, M Younas, and MA Kakar. 2008. Camel a potential dairy animal in difficult environments. Pakistan Journal Agricultural Science 45(2): 263-267.

doi:10.1186/2041-7136-1-3

Cite this article as: Kakar et al:: Rapid change of strategy is necessary for development of dromedary camel

pastoralism in the Cholistan desert of Pakistan. Pastoralism: Research, Policy and Practice 2011 1:3.

\section{Submit your manuscript to a SpringerOpen ${ }^{\circ}$} journal and benefit from:

Convenient online submission

Rigorous peer review

- Immediate publication on acceptance

- Open access: articles freely available online

- High visibility within the field

- Retaining the copyright to your article

Submit your next manuscript at $\gg$ springeropen.com 